\title{
Selected Reference Books of 1953-1954
}

\section{INTRODUCTION}

T IKE THE PRECEDING ARTICLES in this 1 semi-annual series ${ }^{1}$ this survey is based on notes written by members of the staff of the Columbia University Libraries. In this issue, these include assistants from the Reference, Science and Fine Arts Departments. Notes written by assistants are signed with initials. $^{2}$

As the purpose of the list is to present a selection of recent scholarly and foreign works of interest to reference workers in university libraries, it does not pretend to be either well-balanced or comprehensive. Code numbers (such as Gr3 and IA38) have been used to refer to titles in the Guide $^{3}$ and its first Supplement.

\section{BIBLIOGRAPHY}

Totok, Wilhelm and Weitzel, Rolf. Handbuch der bibliographischen Nachschlagewerke. Frankfurt am Main, Klostermann, 1954. 258p. DM 8.50.

A selective bibliography of bibliographies, less extensive than Malclès, Les sources $d u$ travail bibliographique (Guide Suppl. 1A101) and intended mainly for student use. Emphasis is placed on European and American works, although there are some titles listed for Russia and the Far East; Latin America, Africa, and Australasia are omitted.

In two parts: first, a general section, covering national bibliographies, encyclopedias, library catalogs, biography, periodical indexes,

1 COLLEGE AND RESEARCH LIBRARIES, Januaty and July issues starting January 1952.

2 Reference Department: Eleanor Buist, Mary Cun${ }^{2}$ Reference Department: Eleanor Buist, Mary Cun-
ningham, Olive Johnson, Kenneth Lohf, Eugene Sheehy, John Neal Waddell.

Science Libraries: Rosalie M. Saitta, Russell Shank, Edward A. Swierzb.

Fine Arts Library: Mary W. Chamberlin.

a Winchell, Constance M. Guide to Reference Books. 7 th ed. Chicago, ALA, r951; Supplement, Chicago, ALA, 1954 . etc., and second, subject bibliographies. Entries are annotated, but information is brief and occasionally incomplete or misleading.

The introductory text to each section gives an outline of the types of books covered and their uses.-O.J.

\section{PERIODICALS}

Ranganathan, Shiyali Ramamrita. Union Catalogue of Learned Periodical Publications in South Asia. Published with the assistance of UNESCO. London, Indian Library Association, 1953-. v.I. $£_{3 .}$. (In progress).

Vol. I of a planned three volume set is devoted to the physical and biological sciences. Vol. 2 will deal with the humanities and social sciences, and vol. 3 , generalia and a cumulative alphabetical index. The work is based on information received from 210 libraries in Indonesia, Malaya, Thailand, Burma, Ceylon and India. The editor fears that this volume contains many inaccuracies, and indicates that a revised edition will be brought out. Arranged by the Colon classification system, the individual entries give the history of the periodical, and tell the volumes or years held by participating libraries. An alphabetical index (subject, title, sponsoring body, country of publication) refers back to the class-mark. -M.C.

Tortajada, A. and Amaniel, C. de. Materiales de investigación. Indice de artículos de revistas (r939-r949). Madrid, Consejo Superior de Investigaciones Científicas, Biblioteca General, 1952. 2v. 250 Pesetas.

A new and valuable periodical index covering 128 journals from the sciences and the humanities, but since it is based upon periodicals issued by the Consejo, the index does not include many of Spain's important academic journals. The alphabetical listing combines 
authors and subjects, and the headings used were based upon the Library of Congress, Sears, and other standard guides. Succeeding volumes are planned.-K.L.

\section{DISSERTATIONS}

Master's Theses in Science. 1952-. Washington, Biblio Press, 1954-. v.I- . \$7.00.

First of a proposed annual list in the field of pure and applied science, the work includes some 5,588 entries from 138 institutions. Items are numbered and arranged alphabetically by title under general subject. There is an index by institution, but none by author or specific subjects.-E.S.

\section{RELIGION}

American Theological Library Association. Index to Religious Periodical Literature, 1949-1952. Compiled and edited by J. Stillson Judah with the assistance of Leslie Joan Ziegler. [Chicago] American Theological Library Association, 1953. 220p. $\$ 6.00$.

A joint effort of the 22 theological seminaries of the Association, this is a subject and author index to 31 periodicals not indexed elsewhere. The latter section of the volume is a supplementary author index of book reviews selected from most of these periodicals. Succeeding volumes are planned.-K.L.

The Encyclopaedia of Islam. New ed.

Prepared by a number of leading orientalists; edited by J. H. Kramers, H. A. R. Gibb, and E. Lévi-Provençal under the patronage of the International Union of Academies. Leiden, Brill; London, Luzac, 1954- . v.I, fasc. I- . Gld. Io per fasc. (In progress).

For first edition, 1911-38, see Guide K255. A completely new edition expanded to include the results of recent research, in general it covers the same fields as before but with more information on economics, social matters, and art. Bibliographies accompany each article but details for the most frequently quoted works are found only in a composite bibliography at the beginning of each fascicle.

To be complete in five volumes of about I280 pages, six fascicles of 64 pages each will be published annually. A general index and an atlas of the Islamic world are planned to complete this edition.-M.C.

\section{SOCIAL SCIENCES}

Académie diplomatique internationale. Dictionnaire diplomatique, comprenant les biographies des diplomates, du Moyen Age à nos jours, constituant un traité d'historie diplomatique sur six siecles, publié sous la direction de M.A.F. Frangulis. Genève, Paris, N.Y., Montevideo, Londres [1954?] I 26 I p.

An international biographical dictionary of diplomats including names from the Middle Ages to the present. Some articles are signed and some include bibliographies.

\section{Linton, George E. The Modern Textile}

Dictionary. N.Y., Duell, Sloan and Pearce, 1954. 772 p. \$12.50.

Compiled by a specialist and covering the textile and related fields in their current and historic, domestic and foreign, general and specialized aspects. The following are represented: apparel, asbestos, color, history of costume, dyeing, fabrics, fashion and style, fibers and yarns, finishes and finishing, knitting, labor, lace, leathers, man-made and synthetic fibers, manufacturing processes, plastics, printing, sciences used in the trade, and spot and stain removal and care of clothing. There is a 32-page section of illustrations with cross references from the text, as well as charts and tables throughout.-K.L.

\section{Lytle, William M. Merchant Steam Ves-} sels of the United States, I807-I868. "The Lytle List," comp. from official merchant marine documents of the United States and other sources. Ed. with an introd. by Forrest R. Holdcomper. Mystic, Conn., Steamship Historical Society of America, 1952[i.e. I953]. 294p. (Steamship Historical Society of America Publication no. 6). 
A revision and enlargement of Merchant Steam Vessels of the United States, I807-1856, comp. under the author's supervision and issued by the Bureau of Navigation in I93I. Precedes in date Merchant Vessels of the United States, I866/67, published by the U. S. Bureau of Customs. (Guide $\mathrm{L}_{403}$ ).

Gives information on name, tonnage, year and place built, first home port and disposition. There is a separate list of ships lost and one of ships converted to steam.

\section{U.S. Library of Congress. Census Library} Project. Statistical Bulletins; An Annotated Bibliography of the General Statistical Bulletins of Major Political Subdivisions of the $W$ orld, prepared by Phyllis G. Carter. Washington, 1954. 93p.

At head of title: U.S. Library of Congress. Reference Dept., U.S. Dept. of Commerce. Bureau of the Census.

A companion to its Statistical Yearbooks (1953). (See COLLEge AND RESEARCH LIBRARIES I 5 :294, July 1954).

Lists periodicals issued by an official agency more frequently than annually, covering statistics in several subject fields. Arranged by continent and then by country. Indicates beginning date, frequency, categories of statistical data, holdings in Washington libraries, etc.

\section{DICTIONARIES}

Raventós, Margaret H. A Modern Spanish Dictionary. London, English Universities Press, 1953. I23p. 45s.

Aimed at being up to date, this new and excellent Spanish-English, English-Spanish dictionary has been compiled to meet the particular needs of English-speaking readers and students. While obsolete words have been excluded, special attention is given to current scientific, political and social terms, such as cathode rays, atomic pile, Atlantic Charter, iron curtain, nylon stockings, etc. For each part there is a separately paged section giving geographical names whose spelling differs in the two languages, proper names, abbreviations, weights and measures, and currency. -K.L.

Wortabet, John and Porter, Harvey. Eng-
lish-Arabic and Arabic-English Dictionary; with a Supplement of Modern Words and New Meanings, by John L. Mish. N.Y., Ungar, 1954. 455p. ; 423p. $\$ 8.50$.

A reprint of a basic dictionary, long out of print, with a selection of modern words and expressions appended as a supplement, which "should enable the student to read the average Arabic newspaper or book without missing the sense of many words." There is still an apparent need for a comprehensive modern dictionary of the language.-K.L.

\section{SCIENCE}

Who's Who in British Science, 1953.

London, Leonard Hill, I953. 292p. $42 \mathrm{~s}$.

This first edition lists more than 3,000 names in all fields of British science, pure and applied, in industry, research and the universities. Gives personal and professional details.

\section{PHYSICS}

Whitford, Robert H. Physics Literature; A Reference Manual. Washington, Scarecrow Press, 1954. 228p. \$5.00.

A carefully selected list of titles on physics and peripheral subjects. Presented in three sections, the first two listing titles according to "tool" uses-bibliographical information, history, biography, etc. The subject approach comprises the third section. Each chapter is introduced with brief definition of scope and aims and with mention of related sections. Library terminology is used so extensively that some expansion or simplification of language might make it more useful to the scientist and teacher. The occasional annotations are good. Format leaves something to be desired. It is especially valuable as a listing of a nucleus collection for a physics library.-R.M.S.

\section{CHEMISTRY}

Haynes, Williams. American Chemical Industry: A History. N.Y., Van Nosstrand, I945-1954. 6 vols. il. \$15.00 per vol.; $\$ 76.00$ per set.

Vol. I : Background and Beginning, I608-I 9 II. 
Vols. 2-3: The World War I Period, I 9 I 2-I 922 .

Vol. 4: The Merger Era, 1923-1929.

Vol. 5: Decade of New Products, 1930I939.

Vol. 6: The Chemical Companies; Company Histories to 1948 .

An encyclopedic work in 6 volumes, published during the ten-year period, I945-1954, American Chemical Industry aims to trace the development of chemical manufacturing in the U.S. from I608-1948. This comprehensive history is the work of Williams Haynes, editor of Chemical Who's Who (Guide, N2I4) and author of numerous publications dealing with the chemical industry. In many respects the set embraces many excellent reference features. The chapters are well documented with footnotes and extensive bibliographies. Each volume has a company and personal name index as well as a subject index; unfortunately there is no cumulative index for all six volumes. There are numerous portraits scattered throughout the text. Appendices contain much useful material, statistical as well as bibliographical.-E.A.S.

\section{ETHNOLOGY}

\section{Murdock, George Peter. Ethnographic}

Bibliography of North America. $2 \mathrm{~d}$ ed. New Haven, Human Relations Area Files, 1953. 239p. $\$ 3.15$.

The I94I edition (Guide $\mathrm{N}_{3} \mathrm{I}_{2}$ ) is photographically reprinted and all new and corrected references are added as an appendix. New material is listed through 1950. The listing is classed by geographical area, and there is an index of tribal names but no general index. Also included is a map of tribal areas. -K.L.

\section{ENGINEERING}

American Petroleum Institute. Division of Refining. Glossary of Terms Used in Petroleum Refining. N.Y., I953. I88p. $\$ 1.50$ unbound; $\$ 3.00$ bound.

This glossary, which aims to interpret correctly petroleum terminology, is limited to terms commonly encountered in the refining branch of the petroleum industry. The defini tions are intended for general, rather than technical usage, and are not to be construed as authoritative or specific definitions for legal purposes. The glossary is actually a compilation, as definitions were selected from various published sources, such as Chamber's Technical Dictionary, Hackh's Chemical Dictionary, Hutchinson's Technical and Scientific Encyclopedia, as well as other similar reference works. However, the individual source from which each definition was taken is not indicated. The definitions themselves are rather short, averaging 3 or 4 lines each; pronunciation is given for each term. Cross references are liberally used.-E.A.S.

Woldman, Norman E. Engineering Alloys: Names, Properties, Uses. $3 \mathrm{~d}$ ed. Cleveland, American Society for Metals, I 954. I034p. \$I 5.00 .

Contains useful data on 19,280 proprietary, commercial and technical alloys, containing nearly all the alloys manufactured in the United States and many from foreign countries. The text is divided into five sections: (I) alloy index listing alloys by trade name; (2) alloy data giving composition properties, uses, with a key to the manufacturers; (3) directory of manufacturers; (4) index relating manufacturers to alloys; (5) useful data appendix. A first-class ready reference aid which should prove useful to public rollege, and special libraries.-R.S.

\section{PRINTING}

Ascarelli, Fernanda. La tipografia cinquecentina italiana. Firenze, Sansoni antiquariato, 1953. 259p. il. (Contributi alla Biblioteca bibliografica italica. I).

A useful compilation of information about printers active in Italy in the 16 th century. Arrangement is geographical by region, then alphabetical by city, then chronological by printer. Adequate indices.

\section{FINE ARTS}

Gunnis, Rupert. Dictionary of British Sculptors, 1660-1851. London, Odhams Press [1953]; Cambridge, Mass., Harvard University Press, 1954. 514p. il. 63s. ; \$1 2.50 . 
This "attempted dictionary of British sculptors" contains more than I 700 individual entries for sculptors working in Great Britain between 1660 and 1851 . Under the name of each artist is given his dates, a short biography and a list of signed or documented works. For important artists a fairly complete list of their works is included, while for minor craftsmen only their best productions are mentioned. Sources consulted are mentioned in the preface and references to authorities are made under the individual artist entries. Indices of places and of names (other than those of the artists) add to its usefulness. -M.W.C.

The Pelican History of Art, edited by

Nikolaus Pevsner. London, Penguin

Books, 1953- .

The projected 48 volumes of this English language history of art are scheduled to appear at the rate of 4 volumes a year (at the moderate price of $42 \mathrm{~s}$ a volume) and will cover the art and architecture of the East and West from prehistoric times to the present day. Each volume, written by an outstanding British or American scholar, contains 250 to 300 pages of text and about 190 pages of halftone plates as well as plans and drawings in the text. The inclusion of a bibliography, notes and index in each volume, and in some cases of a glossary of terms makes each volume a convenient handbook to the art of that particular period. The volumes which have appeared so far are: Waterhouse, Ellis Kirkham. Painting in Britain, 1530-1790 [1953] Rowland, Benjamin. The art and architecture of India; Buddhist, Hindu, Jain. [1953] Summerson, John. Architecture in Britain, 1530 to 1830 . [1953] Blunt, Anthony. Art and architecture in France, I50o1700. [1953] Rickert, Margaret. English medieval painting. [1954]-M.W.C.

\section{MOVING PICTURES}

Padua. University. Centro cinematografico. Bibliografia generale del cinema. Bibliographie générale du cinéma. General Bibliography of Motion Pictures. A cura di Carl Vincent, Riccardo Redi e Franco Venturini. Roma, Edizioni dell' Ateneo LI953। 25Ip. \$6.00.
International in scope, this listing of several thousand titles constitutes a useful collection of books and, to a lesser extent, periodical articles on the major aspects of the subject. Representation of European and American titles is well balanced, and the tri-lingual text is a helpful feature. Materials are grouped under eleven general headings, with further subdivision in some cases; unfortunately, the index of personal and corporate names only is inadequate for this kind of arrangement, so that a good deal of searching is often necessary for titles on a specific subject. Many of the citations are bibliographically incomplete, and the proof-reading, at least of English names and titles, has been particularly careless.J.N.W.

\section{LITERATURE}

Drevet, Marguerite L. Bibliographie de la littérature française, 1940-1949. Complément à la Bibliographie de H. P. Thieme. Genève, Droz, 1954- . fasc. I- . (In progress).

This is a continuation of the bibliographies of modern French literature by Thieme (Guide $\mathrm{R}_{578}$ ) and Dreher and Rolle (Guide $\mathrm{R}_{57 \mathrm{I}}$ ), and is arranged in similar form: The original list of periodicals indexed has been enlarged and new authors have been added. To date three fascicles have been received covering A to Julien Green.

Leclaire, Lucien. A General Analytical Bibliography of the Regional Novelists of the British Isles, I800-1950. Paris, Belles Lettres, 1954. 399p. \$4.25.

A useful compilation based on three main periods-I800-1830, I830-I870, after I870representing the growth of the genre from the novel of national manners to one with a conscious regional basis. For each author there are brief biographical notes, a listing of the novels pertinent to the scope of the work, their various editions, and the scene of each novel, wherever ascertainable. The editions listed are largely English, although for the more recent works some attempt is made to include American imprints. While many minor novelists are covered, it is difficult to see why George Eliot was included and not Jane Austen, or Liam O'Flaherty and not 
James Joyce. There are indices of authors' names, place-names, and authors' names arranged under regions, as well as two maps, one with names of authors, the other with place-names important to the regional novel as treated.-K.L.

\section{Olzien, Otto. Bibliographie zur deutschen} Literaturgeschichte. Stuttgart, Metzlersche Verlagsbuchhandlung, I953. 156p. (Annalen der deutschen Literatur. Ergänzungsheft 2.) DM I 5.

Includes some sources covered by more comprehensive bibliographies, but emphasis is here placed on work published since J. Körner, Bibliographisches Handbuch des deutschen Schriftums, 1949 (Guide R508), through the end of 1952. Includes bibliographies of individual authors arranged alphabetically.O.J.

\section{Woledge, Brian. Bibliographie des romans} et nouvelles en prose francaise antérieurs a 1500. Genève, Librairie Droz, I954. I8op. (Société de publications romanes et françaises. 42 ).

Arranged alphabetically by author, except for title entries of anonymous works, or works appearing in more than one version each by a different author. The compiler has tried to give the following information about each item: the standard work to be consulted, location of mss., early editions, modern editions, date of composition, source of material, clues to identity of author. In the preface and within the entries are many references to articles or books concerning individual novels or short stories, or these literary forms in general. There are six indices listing I) mss., 2) printers, 3) authors, works, and literary themes mentioned, 4) place-names, 5) patrons, and 6) abbreviations.-M.C.

\section{GENEALOGY}

Bailey, Rosalie Fellows. Guide to Genealogical and Biographical Sources for New York City (Manhattan), I783-I898. N.Y., The Author, 6o E. 80 St., 1954. 98p. $\$ 4.50$.

As either a specialized bibliography or a manual of procedure in genealogical research, this work should prove frequently useful to the general librarian and invaluable to the specialist. "Revised from The New England Historical and Genealogical Register, v. I0608, 1952-54," the guide consists of two main chapters, the first treating the period to 1855 , the second continuing to 1898 . Materials in each are arranged under a variety of classifications, such as court records, vital statistics, general and special directories, street maps, church registers, etc. Library and archival locations are given for collections as a whole and for types of material as well as for individual titles, and the explanatory text is pointed and clear. There is an adequate topical index, but the inclusion of titles cited in the text would have been helpful.-J.N.W.

\section{HISTORY}

Binani, G. D. and Rama Ráo, T. V. India -at a Glance. (A Comprehensive Reference Book on India). [Calcutta] Orient Longmans [1953] i 896 p. $\$ 20.85$.

Aimed at presenting "as succinctly and coherently as possible an all-round picture of the nation." Contains, in addition to brief articles and factual summaries, much statistical and directory-type information as well as some biographical sketches. Arrangement is by topic, and various aspects of government, politics, industry, finance, education, art and culture, etc., are treated. Sources for statistical tables are seldom given, but heavy reliance on government and official sources is asserted in the Preface. There is a general index, though there are numerous errors in alphabetization.-E.S.

Gebhardt, Bruno. Handbuch der deutschen Geschichte. Hrsg. von Herbert Grundmann. 8. vollständig neubearbeitete Auflage. Stuttgart, Union Deutsche Verlagsgesellschaft, I954- . V.I- . Frühzeit und Mittelalter. RM34.

Scholars associated with several German universities have contributed chapters to a thoroughly revised eighth edition of this compendium of German history which first appeared in $1891-92$. Cultural developments are 
now incorporated with the general political account; constitutional, economic and social history receive separate treatment. The first volume covers the period from the origins to the end of the I5th century. Sources and general bibliography, listed at the beginning of each chapter, are supplemented by extensive bibliographic notes on subordinate topics, with particular attention to the literature of research on disputed points. Two additional volumes are announced, volume two to cover the period to the beginning of the Igth century, and volume three to the present.-E.B.

\section{India: A Reference Annual. 1953-}

Delhi, Ministry of Information and Broadcasting, 1953- .

"Compiled by the Research and Reference Division."

A general governmental yearbook, comprising considerable directory-type statistical and textual information on the major services of the national government and the activities of the country as a whole.

Institute of East Asiatic Studies. Korean

Studies Guide. Berkeley, University of California Press, 1954. 220p. \$3.50.

A topically arranged "handbook of basic information for pursuing the study of the various aspects of Korean culture." Each chapter has a brief introductory statement outlining the subject treated, followed by an annotated bibliography of the important works, Western and Oriental. Items are numbered, and there are separate author and title indices. Emphasis is on historical materials, and the natural sciences are almost entirely excluded.
Appendices include a list of rulers, publishing houses and societies, and a glossary.-E.S.

Jerusalem. Hebrew University. Economic Research Institute. A Selected Bibliography of Articles Dealing with the Middle East, 1939-1950. Jerusalem, I954. 95p. \$2.00.

Confined to materials in the periodical collection of the Institute, the work includes articles in Hebrew, English, French, German and Italian relating to Middle Eastern political, social, cultural and economic conditions. Israel and Palestine are omitted (being separately covered, Guide $\mathrm{V}_{408}$ ), as is material on the oil controversy for which a future bibliography is proposed. Arrangement is by subject under country, with numbered entries in the original language, an English translation following the Hebrew listings. Preface and subject headings are in English and $\mathrm{He}$ brew. There is no author index.-E.S.

Mylius, Norbert. Afrika Bibliographie, 1943-195I. Wien, Verein Freunde der Völkerkunde, 1952. 237p. 40 Sch.

A mimeographed bibliography of African folklore and allied disciplines, based on the collections of the Wiener Museum für Völkerkunde, which includes titles of works published from 1943 to July 1952 , thus supplementing H. A. Wieschoff, Anthropological Bibliography of Negro Africa (Guide N316) which covered through 1942 . After general sections which list bibliographies and periodicals, the material is arranged by geographical regions and subdivided by subject. Periodical articles are not included.

\section{Excerpt from "Dues Blues"}

From Stanford Library Bulletin, vol. VI, no. 23, February 25, 1954:

"As if we didn't have trouble enough with income taxes, car registrations and the flu epidemic, the library associations have ganged up on us again with those greetings which arrive every year about this time...

"The question that always pops up when these bills for dues are received is "What have these associations done for me?" And the answer is likely to be, "Well, there's the annual conference, and the district and chapter meetings, and then the Bulletin-"...

"These incidentals to membership, the conferences and the journals, are in fact the least important reasons for joining the associations. The great thing is that, being committed to a profession, dependent on it for our daily bread, and attached directly to it willy-nilly for 35-40 hours a week, it behooves us to concern ourselves with the improvement of it, of the institutions or the committees it serves, and the conditions under which we must work at it." 